\title{
Effective Communications among Woman Legislators on Improving Life Quality in Jember Regency
}

\author{
Juariyah $^{1}$, Ria Angin ${ }^{2}$ \\ ${ }^{I}$ Science Communication Study program, University of Muhammadiyah Jember, Indonesia \\ ${ }^{2}$ Faculty of social and political science study programs, University of Muhammadiyah Jember, Indonesia \\ email: juariyah@unmuhjember.ac.id
}

\begin{abstract}
The present study investigates effective communication among woman legislators in realizing gender budget as a way to improve life quality of women in Jember regency. The research method implemented in this study is qualitative with in-depth interview as its data collection technique. The effective communication depicts a design of information delivery performed by a communicator to an interlocutor. Alo Liliweri (1997) mentions 8 determining variables in a process of effective communication, namely (1) sender, (2) background, (3) message/stimulation/stimulus, (4) channel/media, (5) receiver, (6) feedback, (7) entropy, and (8) situation or atmosphere. The findings indicate that effective communication among women legislators includes building favorable interpersonal relationship with their constituents, thus creating a fanatic constituents. Another form of effective communication is by intensively holding a village-based aspiration hearing forum which involves the local community. Through this forum, the people can deliver their problems face to face and the attending members of the board can give applicable solutions, therefore feedback can be immediately uttered.
\end{abstract}

Keywords: effective communication; favourable communication; aspiration hearing forum

\section{Introduction}

The total number of constituents in Jember Regency indicates that female constituents outnumber the male ones. Yet, the number of woman legislatives in the regency is low. Such a phenomenon of imbalance quantity of women and men legislators is a challenging moment for the women legislators to construct strong roles in influencing political processes taking place in the legislatives. The capacity of a woman legislative in playing her roles as a people representative is mostly dependent on her capability in performing effective communication with the people or women whom she represents, making it vital and strategic. The process of effective communication somehow can eradicate any negative accusation and opinions related with the poor performance of the legislators.

Previous studies on the roles of effective communication in politics performed by women legislators have been conducted; the first was done in 2007 focusing on gender issue in General Elections of Mayors/Governors (Juariyah, 2007). This study found that gender is 
an issue that has been effectively communicated during the campaign and can win the representatives in the election. The second study was done in 2009 entitled Political Marketing of Women Represenntatives in General Election (Angin, 2009). Some strategies of effective communication were identified which could be applied to get as many votes as possible. Meanwhile, the third study is entitled "Communication Media of a Party towards Women" and found that by implementing effective communication strategies, the political parties can get the sympathy of women constituents (Angin, 2010). Another study on Women in Jember Regency (Supeni, 2012) is entitled Woman Economic Empowerment, Crediting, and Development of Women-Empowered SMMEs depicting that the conduct of ODA performed by Semesta Nur significantly affects the development of women-empowered SMMEs. Another study entitled the State of Independence of Ex-Female Workers in Managing Remittance and Building Local Economic Potentials by Integrating Information Technology Center (ITC) (Wahyu, 2013) shows that ITC has become a positive means of developing and strengthening business channels with the country in which they were working. Therefore, the present study aims to uncover the communication attempts initiated by women legislators with constituents or other legislators in their roles as the board of representatives in Jember Regency in order to propose programs for improving life of women.

\section{Theoretical Framework}

\section{II.1. Concept of effective communication process}

The term 'communication' comes from Latin 'communis' which means to create a mutual state, or to share something in common between two or more people. Communication is defined as an interaction, symbolic process that allows people manage their environment by (1) building interpresonal relationships, (2) exchanging information, (3) to reinforce attitude and behavior of others, and (4) to attempt to change attitude and behavior (Cangara, 2004:18). Another definition of it is a process of transmitting an idea from a source to a receiver or more, by aiming to change behavior. The latter definition is then developed into a process of two or more people create or exchange information from one to another, which later in-depth mutual understanding will take place (Cangara, 2004:19)

Alo Liliweri (1997) mentions 8 highly determining variables in the process of effective communication, namely (1)sender, (2)background, (3)message/stimulation/stimulus, (4)channel/media, (5)receiver, (6)feedback, (7)entropy, and (8)situation or atmosphere. Each of the eight will be described in the following: sender in a communication process, Mulyana and Rahmat (1990) define that it is a communicator or person or what this study defines as legislators who attempts to send a message or information; background is experience or reference of a sender that affects his/her way of thought, feeling, or behavior. Background is made of some characteristics, such as demographic, geographic, and psychographic characteristics; message/stimulation/stimulus in a communication process can manifest in a regular or irregular stimulus. The regular stimulus is a stimulus or message which is wellarranged, complete, countable, and understandable as a message that can be analyzed and understood; channel/media is the path through which the message is transmitted; receiver or interlocutor or in this study is constituents who receive messages from the legislators; feedback in a communication process is a receiver's response towards a message indicating 
that it has been accepted and understood. The sender, on the other hand, receives its message back in the form of a stimulus from a receiver in the reverse communication process. There are several types of feedback, namely external feedback, internal feedback, direct or immediate feedback, zero feedback, neutral feedback, positive feedback and negative feedback. Entropi is a concept which describes how a communication message is troubled thus misses its target. Atmosphere is the environment where a communication process occurs.

In regards with the aforementioned theory, the communication process aims to achieve several objectives (Bungin, 2006), as follows; attitude change, opinion change, behavior change, and social change. Meanwhile, Effendi (2006) argues that effective communication will lead to four effects, such as: Cognitive effect, occurring on an interlocutor that makes $\mathrm{him} / \mathrm{her}$ know something or improves his/her intelligence. In other words, the communication aims to change an interlocutor's way of thinking. Affective effect, in a level higher than the cognitive effect, is an aim of communication to get beyond knowing; to move his/her heart, raise a certain feeling, like being compassionate, carried away, inconsolable, excited, angry, and so on. Finally, behavioral effect is an effect on an interlocutor that is manifested in behavior, attitude, or habit.

\subsection{Represented Community (Constituents)}

The community whom the legislators represent is called constituents. The constituent is all members of the community living in the constituency where a legislator is elected in the General Election. His or her supporters or people who choose him/her as a legislator are the primary constituents. Meanwhile, after the conduct of General Election, every member of the community who lives in this constituency also belong to his/her constituents; therefore, the legislator cannot disregard them. Briefly speaking, constituents of a legislator are all members of community whose domicile is his constituency. This should make the legislator closer to the community he/she represents and take the struggles for their aspirations and interests before the board. Based on this description, it is worth saying that constituents hold the true authority.

The aforementioned condition, according to Kouzes and Posner (2000), once a person is elected by a constituent; in essence a transaction or mutual agreement or understanding has taken place. Such transaction comprises of agreement, division of roles, and distribution of duties. As it is a transaction, the people involved should fulfill rights (to act on behalf of the constituents, to be in a position, to receive facilities of the position, and so forth) as well as responsibility to serve the needs of the constituents.

Furthermore, there are four types of legislators (Gilbert Abscarian, in Yuni Thamrin, 2009): the trustee if they are capable of knowing, formulating, and actualizing every interest and need of the state and the community they represent (the constituents). However, if tradeoffs happen between the need of the state and of the constituents, the legislators are not tied to their constituents; instead they prioritize the nation beyond everything; the delegate, they generally prioritize their constituents over the nation. During the process of legislation, budgeting, and supervision of the government, this type of legislators are strictly lead by the importance of their parties; the partisan, is a type of legislators who are not only bonded by the parties but also to their ideologies; the politico, this is a type which includes all previous types plus their conscience. This very type of legislators will always act on behalf of their conscience, their constituents, and their parties simultaneously. 
Moreover, Ann Philips in her book The Politics of Presence (1995) posits that women legislators have actually been a symbol of women representation. Their presence in the legislatives shows their capability of struggling for ideas and opinions that represent aspirations and needs of women in their constituencies.

\subsection{Accomodative Attitude}

Attitude is a tendency whether to get closer or away, behave positively or negatively towards certain social circumstances, be it an institution, person, situation, idea, concept, and so on (Howard and Kendles, 1974, Gerungan, 2000). Meanwhile, Gagne (1974) defines that attitude is an internal state that which affects an individual's choice over objects, persons and

phenomena. Further, attitude is made of three components, namely cognitive, affective, and conative or a tendency to react (Gerungan, 2000). The first component, cognitive, is an aspect of attitude relating to individual judgment towards an object or subject. Any information input to the human's brain that has been through the process of analysis, synthesis, and evaluation will result in new values which then will be accomodated or assimilated by the prior knowledge existed previously inside the brain. New values thought to be true, excellent, attractive, and so forth, eventually will affect emotion or affective component of a person's attitude. Therefore, affective component can be regarded as feeling (emotion) of an individual towards an object or subject, that goes in line with his judgment. On the other hand, the conative component is related with an individual's willing to do something in accordance with his belief and wills. A person's attitude towards an object or subject may be positive or negative. The attitude manifests itself in responses whether the individual accepts or declines, agrees or disagrees with an object or subject. All of the three components are interrelated. From which ever we start our analysis on an attitude, they will still be in a binding system. Therefore, a person's attitude is highly correlated with their behavior. Once the attitude factor affects or raises a person's attitude, the attitude and behavior will be consistent, as mentioned by Krech and Ballacy, Morgan King and Howard.

According to the above mentioned description, the accomodative attitude of legislators towards aspirations and the needs of the people or women to whom they represent may be observed from their cognitive, affective, and behavior components. Therefore, to see how the cognition state of a legislator towards the constituents' aspirations and needs is by observing how far she understands these aspirations and needs in the constituency. On the other hand, the affective aspect of a legislator on her constituents' aspirations and needs can be watched through her emotional level towards them in the constituency. Yet, the conative attitude of a legislator towards her constituents' aspirations and needs can be seen from her behavior as she reacts towards the aspirations and needs that is reflected in her attitude of encouraging or discouraging these aspirations and needs in order to be further accommodated by the regional government to become a regional development program.

\subsection{Women in Politics}

One of popular myths among the people is that women are not allowed to take part and work in politics related world. This makes harder for women to consolidate her position in politics. The attempt to escalate the quantity of women in the Parliament is still done in order to balance the representation of women and their voices, yet this attempt obtained only 
the quantity, not the quality of their voices and strategic roles as policy makers among the political domain (Subiakto, 2014:182).

The data of women enrolled in politics was started in 1992-1997; the total number of women in the Indonesian Parliament was 63 women in the legislatives, or about $12.3 \%$ of all members of legislatives. In 1997-1999, or known as the Reformation era, there were 57 women who got the seats in the legislatives, or $11.5 \%$. Furthermore, in $1999-2004$, there was a decline in the number of women legislators, which were 45 people. In 2004, an idea of the $30 \%$ quota for women came up. Nonetheless, almost every political party at the time was not ready with their cadres and candidates for filling up the quota, leading to the phenomenon of taking relatives, or cadres who suddenly come up to the show (Subiakto, 2014:183).

Since the conduct of the 2004 General Election, the idea of $30 \%$ quota emerged and the Law of General Election also regulated that it has to be applied for the 2009 General Election. In average, this quota was well equipped in both central and local Parliament, however, the ability of political communication of the elected members was still somehow below expectations. The present study, therefore, aimed to observe the attempt of effective communication performed by the women legislators in Jember Regency in order to improve the life quality of women in Jember.

\section{Methodology}

The present study employed descriptive qualitative method, using in-depth interviews to 7 (seven members of legislatives). It was located in Jember Regency, particulary in constituencies which are represented by women legislators by considering that the people from the constituencies are at the same time the constituents of the legislators.

The data were gathered by survey and in-depth interviews in order to obtain the data and problems in the field with deeper understanding, as well as Focus Group Discussion (FGD). Moreover, the analysis technique implemented was that of qualitative analysis, consisting of some stages, such as data reduction, data display, and conclusion.

\section{Results and Discussion}

\section{IV.1. Results}

From the General Election of Legislatives in 2009, seven women were elected. These seven legislators were positioned in four commissions, namely commission A, B, C, D. Of the four commissions where the women legislators were put into, only the commission $\mathrm{D}$ was more popular as the $s o$-woman commission. However, although the other women legislators were in the man-area commissions, their positions seemed to be less strategic. None of these seven legislators was chosen as the Head of the commission. Yet, the highest position was vice of commission, which belonged to Lilik Niamah (PKS) who was elected as the vice of commission B, and Evi Lestari (PAN) who was chosen for the vice of commission A. Table 1 describes this finding. 
Table 1. Positions of women legislators in the commissions

\begin{tabular}{|c|c|c|}
\hline Commission & Name and Party of Legislators & Position \\
\hline \multirow{2}{*}{ A. Law and Government } & Evi Lestari (PAN) & Vice \\
\cline { 2 - 3 } & Lili Syafiani (Demokrat) & Member \\
\hline \multirow{2}{*}{ B. Economics and Banking } & Lilik Niamah (PKS) & Vice \\
\cline { 2 - 3 } & Chosidah (Gerindra) & Member \\
\hline C. Budgeting & Illa Yadalubi (PPP) & Member \\
\hline \multirow{2}{*}{ D. Social and Education } & Sri Wahyuni (Demokrat) & Member \\
\cline { 2 - 3 } & Ambar Listiyani (Demokrat) & Member \\
\hline
\end{tabular}

Communication is vital for keeping relationship good in all contexts of internal and external, so well as formal and informal context. According to one of the legislators, Lilik Niamah from PKS "formally, we should show our characters". The legislative position formally will grant her authorities. Furthermore, in the formal view, the presence of positions for women legislators in Jember Regency is still low in quantity; only seven out of 50 members. Yet, of the seven elected members, only two are as vices, namely Evi Lestari and Lilik Niamah, while the rests are members of the commissions.

Every interest will be manifested in attitude, action, and roles of every individual in an organization. Therefore, it is expected that every individual's roles, whether consciously or unconsciously, will be aimed to its realization in processes of interaction favorable for others, thus allowing such realization of expectation and pleasant objectives of every individual and organization happen.

In every process of interaction between individuals and organization, there is an emergence of social processes. Such interaction will result in changes, because every social process basically has three internal aspects, namely;

1) Interaction aspect that leads to interplay and self-adjustment.

2) Unity aspect as an effect of self-adjustment which leads to integration.

3) Emerging aspect or presenting new situations, like creating new elements within an interaction situation (Susanto, 1974;177).

Based on the explanation, it is inferred that every individual will perform certain communication effort to achieve a total situation which is an advantage to him/herself.

Furthermore, in performing public related activities, there are several methods of communication which could contribute to good mutual understanding between the women legislators and their constituents. The following model describes in more details.

Figure 1. The Model of Communication Role in Internal Relationships

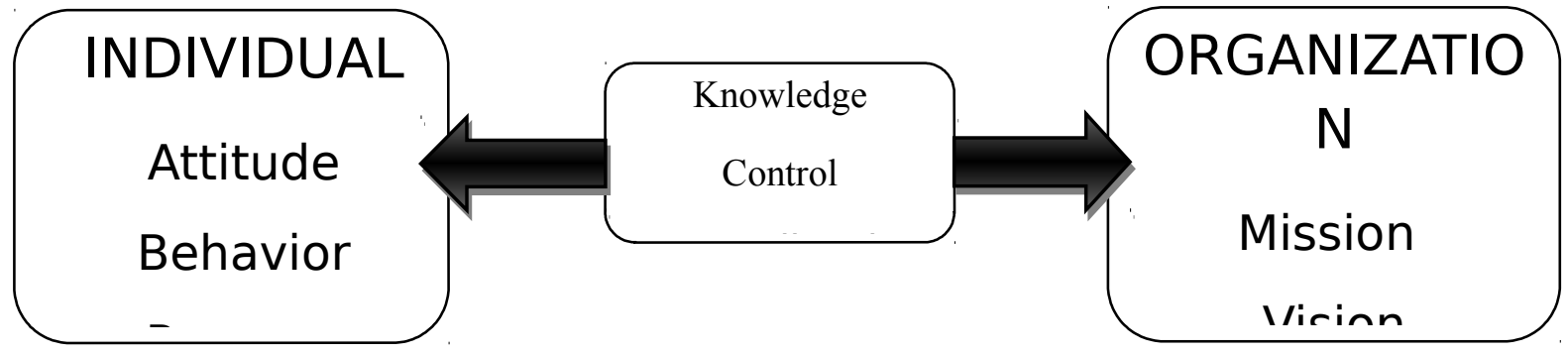


The model describes that communication function in an internal activity is an initiative to unite different interests of performers, thus communication will be more than just "stimulus- response"; it will be the mechanism of coordination, control and interrelationship.

In regards with communication performed by women legislators, the presence of both formal and informal communication was identified. George R . Terry mentions five forms of communication within an organization, as follows

1). Formal communication is the communication happening within the formal course of organization, in which it includes authorities and responsibilities and performed through oral and written instructions following the applicable functional procedures.

2) Non-formal communication is the communication which happens spontaneously as a reaction to unexpected condition yet it is still work-related, such as suggestions to duties, responsibilities, and production.

3) Informal communication is similar to the non-formal form, only that it is characterized to be closer to the aspect of human relation.

4) Technical communication is the communication which is technical by nature, thus it may only be understood by the corresponding parties; for example, design or computerized programs and such.

5) Procedural communication, is the communication which is commonly related to formal communication, like manual for technical work, the company's regulations, and guidelines, and so forth.

The informal communication performed by the women legislators investigated in the present study, as described by Lilik Niamah, emphasizes verbal and non-verbal communication aspect, i.e., the speech is the verbal form, and its intonation and attitude is the non-verbal one.

In relation to the aforementioned finding, verbal communication is the language. Language as a system of verbal code that is constructed by a set of symbols and rules to combine the symbols, used and comprehended by particular communities (Mulyana, 2000:176). In fact, language itself is somehow interrelated with culture, as a hypothesis proposed by Sapir -Whorf, or also known as the theory of linguistic relativity, that every language expresses an exclusive symbolic world, depicting reality of thought, internal experiences, and needs of the users.

Meanwhile, non-verbal communication is every signs but words. According to Larry A. Samovar and Richard E. Porter, non-verbal communication includes every stimulus, except the verbal stimulus within the communication setting induced and the usage of environment by individuals that carries along a potential message for its sender or receiver. Therefore, this definition encompasses every intentional behavior as a part of the whole communication 
event. In other words, we frequently send a lot of non-verbal messages but are not aware of their being meaningful to others.

Like the verbal messages, non-verbal messages are also related to culture, for different culture might result in different interpretations. Universality, however, does not work for both verbal and non-verbal language. The verbal language may take dictionary as a guide for interpreting verbally uttered words according to one's culture; therefore, a special dictionary should also be made for helping out people with non-verbal languages of other cultures. Thus, non-verbal symbols are so much harder to interpret than verbal symbols. Despite all this difficulty, it is important to note that non-verbal language tends to be in line by meaning with its verbal language.

There are several notes for the concept which assumes that non-verbal language is in the same body of verbal language, in which it implies:

(1) If we speak a foreign language, we tend to approach the norms of interpersonal relationship of the language's culture. For example, our gestures may be different when we say "punten" (Javanese word for 'excuse me'), when compared to the words "permisi" (Indonesian word for 'excuse me') or "excuse me";

(2) Every body movement is synchronous with words. In Indonesian culture, we tend to nod when saying 'setuju' or agreed;

(3) Bilingual people tend to have bilingual gestures.

The women legislator who was investigated next was Ambar Liani. She explained that all she has done is to keep and develop interpersonal relationship with her constituents. She has frequently gone deep into villages to get closer to her constituents, and also she never powered off her mobile phones; which means that she would be ready anytime people reach her. She concluded that all she did was to build fanatic constituents.

Interpersonal communication is the most effective form of communication, by far, as uttered by Roger and Shoemaker (1971) in Liliweri, 1997:65 who mention that should you need to communicate well, you have to use more than one senses during your communication, by following these stages: (1) the knowing stage is to see with the sight sense or eyes for as much as $83,0 \%$; (2) the hearing stage is to use the hearing sense or ears as much as $11,0 \%$; (3) the smell stage is to use nose or the smell sense for $3,5 \%$; (4) the touch stage is to use hands for $1,5 \%$; and (5) the taste stage is to use the taste sense as much as $1,0 \%$.

Roger's idea indicates that humans mostly have interpersonal communication in face-toface manner that its intensity reaches $83 \%$. Therefore, the face-to-face communication is still more preferred than other forms of communication, including interpersonal communication using media.

Ambar further explained that she was responsible for the D commission which focused on people welfare, and its specific responsibility was health and health care. She recounted a moment during her service when a woman who had just given birth took a bath in nearby, unhygienic river; which caused her infected and passed away. This made Ambar wanted to 
strive for building local public bathing, washing, and toilet facilities in, for example, the yard of mosques.

The above legislator has a quite different idea from that of Lilik Niamah who thought that communication should be all internal and external, as well as formal and non-formal, while Ambar preferred upgrading interpersonal communication relationship. Furthermore, the researchers could have a chance to meet Evi Lestari at her cozy home who had similar idea to Ambar's. Evi Lestari is one of the seven women legislators in the study who is preparing herself to her candidacy as the Mayor of Jember. Evi explained that she had been conducting the aspiration-hearing forum, which was a brand new model of program implemented in the Legislatives. In this kind of forum, seemingly interpersonal communication is implemented.

Concerning to the forum implemented by Evi, it seems that the response or feedback is received immediately; in other words, the face-to-face interpersonal communication happens when giving undelayed feedback. This feedback distinguishes itself from the mass communication.

The significances of interpersonal feedback communication for every member of the communication are, as follows; every communicator will immediately learn whether their intended messages are received or declined by the interlocutors. If they response messages in exchange and accept each other's presence, so they actually do the dialogic interpersonal communication. Feedback is also significant as an element of enrichment and reinforcement to the interpersonal communication; thus, hopes, interests, and wills of both communicator and interlocutor may be achieved (Liliweri, 2000: 70).

From the aforementioned description and explanation by every woman legislator investigated in the study, it is indicated that their presence and initiatives as woman legislators have shown positive attempts, yet improvement is necessary since the man legislators still currently outnumber the women legislators in Jember Regency.

\section{Conclusion}

The attempt to increase the number of women among the Parliament and Government has been initiated to balance out the representation of women and their voices. However, this attempt might only succeed to achieve the quantity, particularly in Jember. Compared to the quality of women's voices and strategic roles as policy makers in politics, such achievement in quantity is still below the expectations. Even though so, initiatives in building effective communication have been implemented by the women legislators, such as maintaining good internal and external relationship, building favorable communication with men legislators and constituents, and keeping good formal and informal relationship. One of the effective communication initiatives implemented by the legislators is the aspiration hearing forum which involves the local community. This is a very positive attempt because people can directly deliver their problems and immediately the attending members of the board give their responses. Such form of communication is very effective because feedback can be immediately learnt. 


\section{References}

Liliweri, Alo, 1997, Komunikasi antar pribadi, Bandung: Citra Aditya Bakti.

Lusia, Amelita, Wanita caleg sedang bersolek, Femina, No. 11/XXXVII/14-20.

Local Governance Support Program, Legislative strengthening Team, Menjadikan Wakil Rakyat semakin bermartabat, Panduan Fasilitator, Orientasi bagi anggota DPRD, Juli, 2009. 2009.

,Membina Hubungan dengan Konstituen, panduan bagi anggota $\quad$ DPRD, Juli

Boglan, Robert C and Biklen, Sari Knopp. 1982. Qualitative Research for Education: An Introduction to Theory and Methods, Boston: Allyn and Bacon, Inc

Brown, Rob, 2009. Public Relations Social Web And How To Use Social Media and Web 2.0 In Communications, London, Library of Congress Pentonville.

Donsbach, Wolfgang, 2008. The International Encyclopedia of Communication, Victoria: Blackwell Publishing..

Flick, Kardorff, etc, 2004. A Companion to Qualitative Research. London: Sage Publication

John W Creswell, 1993. Research Design: Qualitative \& Quantitative Approach. London: Sage.

Angin, Ria dan Juariyah,.2007. Isue Gender dalam Kampanye Pilkada Kabupaten Jember, Tahun 2005, Laporan Penelitian, Jember: LPPM Universitas Muhammadiyah Jember.

2008.Media Komunikasi Politik Partai terhadap perempuan, Laporan penelitian, Fakultas ilmu Sosial dan Ilmu Politik, Universitas Muhammadiyah Jmeber. dan Haerah, Kahar, 2009, Marketing Politik Caleg Perempuan dalam Pemilu, Laporan Penelitian, Jember: LPPM Universitas Muhammadiyah Jember.

Arinanto, satya, fatmawati, 2009, Buku Panduan tentang Menjalin Hubungan Konstituen dan Keterwakilan, Jakarta: Sekjen DPRI dan UNDP.

Bungin, Burhan, 2006, Sosiologi Komunikasi, Teori, Paradigma dan Diskursus Teknologi Komunikasi di masyarakat, Jakarta: Prenada Media Group.

Kalof, Linda, etc, 2008, Essentials of Social Research. Mc Graw Hill: Open Univrsity Press

McLuhan, Marshall. 1994. Understanding Media:The Extensions of Man, Cambridge: Mass MIT Press.

Michael Bloor, Jane Frankland, Michelle Thomas, Kate Robson. 2001. Focus Groups in Social Research, London: Sage Publication

Norman, Denzim K.Yvonna, Lincoln. 2011. Handbook of Qualitative Research (Edisi Ketiga), Buku 1 Penerjemah Dariyanto, Yogyakarta: Pustaka Pelajar

Patton, Michael Q. 1987. Qualitative Evaluation and Research Method. Newbury Park, etc : Sage

Subiakto, Henry dan Rachmah Ida. 2014. Komunikasi Politik, Media, dan Demokrasi, Edisi Kedua, Jakarta: Kencana Prenada Media Group.

http://e-resources.pnri.go.id:2056/docview/203282481?account id $=25704$ (Diakses: 10 November 2014 jam 09:10

http://e-resources.pnri.go.id:2056/docview/1448424885?account id $=25704$ (Diakses: 11 November 2014, jam $10: 05$. 
Budapest International Research and Critics Institute-Journal (BIRCI-Journal)

Volume I, No 3, October 2018, Page: 225-235

e-ISSN: 2615-3076(Online), p-ISSN: 2615-1715(Print)

www.birci-journal.com

emails; birci.journal@gmail.com

birci.journal.org@gmail.com

http://e-resources.pnri.go.id.2056/docview/1512382173 (Diakses: 12 November 2014, 10:30)

http://e-resources.pnri.ggo.id.2056/docview/1448810156?account $=25704$ (Diakses: 12

November 2014,12:00) 